AGRO EKONOMI, Vol 30, Issue 1, June 2019, Page.1-12

DOI : http://doi.org/10.22146/ae.36942

ISSN 0215-8787 (print), ISSN 2541-1616 (online) Available at https://jurnal.ugm.ac.id/jae/

\title{
EFFICIENCY OF ARABICA COFFEE PROCESSING UNIT IN NGADA REGENCY
}

\author{
Kornelia Ngina Djawa ${ }^{1}$, Irham ${ }^{2}$, Lestari Rahayu Waluyati ${ }^{3}$ \\ ${ }^{1}$ Master Students of Agribusiness Management, Faculty of Agriculture, \\ Universitas Gadjah Mada \\ 2,3Faculty of Agriculture, Universitas Gadjah Mada \\ Jl. Flora No. 1 Bulaksumur, 55281 Yogyakarta, Telp. (0274) 555675 \\ krnldjw@gmail.com
}

Submitted: 13 July 2018 ; Revised : 10 October 2018 ; Accepted: 13 March 2019

\begin{abstract}
Village-based processing unit is a small-scale agricultural processing industry based in rural areas. It is a breakthrough program in accelerating the growth of farmers' income and increased employment. The product processing unit has a goal of obtaining maximum benefit. In order to achieve maximum profit and continuous processing of coffee, the processing unit should pay attention to the efficiency aspect. The purpose of this research is to know the efficiency of the coffee processing unit in Ngada regency and the improvement strategy for processing unit of an inefficient result to be efficient. The analysis method used is Data Envelopment Analysis (DEA) of Charnes, Cooper, and Rhodes (CCR) model and Banker, Charnes, and Cooper (BCC) model with output orientation. The research sample is the management of the coffee processing unit, with the total of 40 respondents. The result of this research shows that the efficiency measurement using DEA method of the CCR model produces coffee processing unit in Ngada regency which efficiently reaches 9 units or $22.5 \%$ while 31 or $77.5 \%$ other processing units are inefficient. On the BCC model unit, the efficient coffee processing is 20 units or 50\%, while the other 20 units or $50 \%$ are in the inefficient state. The inefficient processing unit is because the available input is not used optimally. Inefficient processing units can be achieved efficiently by referring to efficient processing units within their peer groups by adjusting the excessive amount of input usage.
\end{abstract}

Keywords: Arabica Coffee, Coffee Processing Unit, DEA, Efficiency.

Djawa, K.N., Irham., \& Waluyati, L.R. (2019). Efficiency of Arabica Coffee Processing Unit in Ngada Regency. Agro Ekonomi 30(1) : 1-12

\section{INTRODUCTION}

Arabica coffee is one of the plantation commodities that currently has a special market because much of them become a special coffee with a best taste and unique aroma (Sudjarmoko, 2013). The development of arabica coffee still has an opportunity because it has a share of special coffee market that is still open to the shift of ordinary coffee consumers to specialty coffee, especially in consumer countries such as the United States. In a special segment, the coffee price is expensive and the fluctuation is 
not too sharp which affects the income of farmers and foreign exchange.

Based on data of Agriculture and Plantation Office of NTT (Nusa Tenggara Timur) Province in 2016, arabica coffee is one of the main commodities of Ngada Regency. With a total coffee production of 3,549 tons out of 21,217 tons (total coffee production in NTT), Ngada regency ranks first as the largest coffee producer in East Nusa Tenggara.

Soemarno et al., (2009) argued that based on the study of Indonesian Coffee and Cocoa Research Center, arabica coffee from Ngada regency has a potential to become export quality coffee beans with a special taste. It encourages Ngada regency goverment to cooperate with Indonesian Coffee and Cocoa Research Center to accelerate the improvement of arabica coffee quality, through quality improvement and marketing program by organizing training and coaching activities for the coffee farmers. On a national scale, in order to support the improvement of coffee quality and the welfare of farmers in rural areas, the Government through the Ministry of Agriculture, especially the Directorate General of Management and Marketing of Agricultural Products, holds a Program of Increasing the Value of Additional Sector of Plantation with the activities of the village-based processing unit.
The village-based processing unit is a small-scale agricultural processing industry and rural-based households which is a breakthrough program that refers to economies of scale so that service functions can evolve toward improving the quality, quantity, and continuity of production to supply the demand. In Ngada regency, there are currently 92 village-based processing units spread in the villages of coffee production centers. It serves as a place for the farmers' coffee cultivation in order to become a quality coffee product which has a high selling price and can increase the farmers' income.

In the processing units, Hs wet coffee is produced using a number of inputs such as red coffee, water, fuel (gasoline), sack (packed), manpower, and some equipment such as peeler, drying racks, and bucket fermentation. The coffee processing unit has an objective of obtaining maximum benefit from the processing activities undertaken. Thus, the processing unit should pay attention to the efficiency aspect of input use.

According to Timisela et al., (2014) in business management, efficiency is one of the aspects that need to be considered so that there is an increase in business scale. Efficiency is critical to a company's success. Efficiency is not just minimizing cost to a minimum to produce optimal output, but also managing input and output relationship 
in order to provide optimal results (Abidin and Endri, 2010). A company will achieve efficiency if it can allocate a certain number of inputs and produce a higher number of outputs or to produce a certain amount of output by using minimum input. The efficiency of a unit can be obtained if inputs and outputs are used optimally so as to provide benefits. Wijayanti et al., (2016) measured the efficiency of the production of brown sugar agroindustry in Kokap Sub district, Kulon Progo regency, using DEA output orientation of CCR model on 30 DMUs of brown sugar agroindustry with input variables including coconut sap raw material, fuel, supporting materials, labor and costs depreciation and output variables in the form of original brown sugar. The results obtained were 28 inefficient DMUs and 2 efficient DMUs. The causes of the inefficiency was due to the excessive input use. In order to achieve efficient conditions, these excessive inputs must be reduced.

Timisela et al., (2012) conducted a research on the efficiency of sago agroindustry in Maluku province using Data Envelopment Analysis (DEA) output through CCR model on 40 DMU with input variables including raw materials, supporting materials, packaging materials, wood fuels, labor and shrinkage of tools and processing machines. The output of the DMU is the value of the product obtained from sago plate, bagea serut, sago bangket, sago snack, sika sago, sago macron and pearl sago. The analysis of 40 sago agroindustries, found that there were 24 efficient sago agroindustries and 16 inefficient agroindustries. The cause of the efficient occurrence was because of the excessive use of inputs. Therefore, in order to achieve the efficiency, it is necessary to reduce the input of the analysis of the relative efficiency of $40 \mathrm{DMU}$ of sago agroindustries showing that $60 \%$ is efficient and $40 \%$ inefficient. An efficient DMU is used as a reference by inefficient DMU based on recommended lambda weight values. It can improve the use of input and output of inefficient DMUs. The same thing was done by Sari et al., (2014) to get $100 \%$ efficiency of supply chain performance of catfish. Therefore, decreasing input or increasing output at inefficient farmers or bandars was conducted.

The study of the efficiency of the processing of coffee products with the DEA method can be applied to optimize the allocation of the use of inputs and outputs produced. Coffee processing activities carried out by the coffee processing unit or UPH in Ngada regency have the potential to generate maximum profits when paying attention to the efficiency aspects. But until now there has been no research on this matter. 
Therefore, it is very interesting to study the efficiency of processing the coffee produced by UPH in Ngada regency.

Based on the description above, this study aims to measure the efficiency of the coffee processing unit or villagebased processing units in Ngada regency and its inefficient processing unit repair strategy. This research is expected to help coffee processing units to increase profits through efficiency improvements.

\section{METHODS}

The determination of research location was done by purposive sampling method. The location of research is Ngada regency of NTT province because it is one of the centers of Arabica coffee production in Indonesia which is very potential and has an export value. Sampling was done by purposive sampling method. The number of samples of this research was 40 units of coffee processing that applied the processing of Hs wet coffee and sold it directly. Data collection techniques in this study were observation and interview involving farmers' members of the coffee processing unit. Data collection was conducted from May 2017 to June 2017.

Measurement of efficiency in this study using Data Envelopment Analysis (DEA) Solver LV3. The DEA model used were the Charnes, Cooper, and
Rhodes (CCR) model and the outputoriented Banker, Charnes, and Cooper (BCC) model. DEA through CCR model calculates the technical efficiency and scale efficiency, while DEA through BCC Model calculates pure technical efficiency. Technical efficiency explains the efficiency of a DMU in converting inputs to outputs. Mean while, the efficiency scale is the ratio between the efficiency of the CCR model to the efficiency of the BCC model. The efficient scale aims to determine whether a DMU has been efficient or not under optimal production conditions. The CCR model assumes that DMU operates under optimal conditions. Mean while, the BCC Model proposed by Banker et al., (1984) assumes that the DMU has not operated under optimal conditions so that every input and output component can still be optimized to achieve efficiency.

In general, the DEA model for calculating relative efficiency is:

$\mathrm{E}_{\mathrm{pq}}=\max h_{0 \text {, }}$

$h_{o}=\frac{\sum_{r=1}^{s} u_{r} y_{r j o}}{\sum_{i=1}^{m} v_{i} x_{i j o}}$

Subject to:

$$
\begin{aligned}
& h_{0}=\frac{\sum_{r=1}^{s} u_{r} y_{\dot{j}}}{\sum_{i=1}^{m} v_{i} x_{j}} \leq 1, j=1,2, \ldots, n \\
& u_{r}>\varepsilon, r=1,2, \ldots . S \\
& v_{i}>\varepsilon, i=1,2, \ldots . m, \text { with } \varepsilon>0 \\
& \quad \text { Where } h_{0} \text { is efficiency score of } \\
& \text { DMU-j } j_{0}, s \text { as the number of outputs }
\end{aligned}
$$


generated, $m$ as the number of inputs used in coffee processing, $j$ as DMU number, and $n$ is the number of DMU. $y_{r j}$ as the output value, $x_{i j}$ as input value, $v_{i}$ as weighted weight for input value, and $u_{r}$ as weighted weight for output value of DMU.

Equation 1 above can be written in the form of a linear equation using the assumption of variable return to scale (VRS) so that it can be simplified into: Maximize $h_{\sigma^{\prime}}$

$$
h_{o}=\sum_{r=1}^{s} u_{r} y_{r j o}+u_{0}
$$

Subject to: $\sum_{i=1}^{m} v_{i} x_{j 0}=1$

$$
\begin{gathered}
\sum_{r=1}^{s} u_{r} y_{\dot{j}}-\sum_{i=1}^{m} v_{i} x_{j}+u_{0} \leq 0 \\
; j=1,2, \ldots, n \\
\mathrm{u}_{\mathrm{r}}>\varepsilon, \mathrm{r}=1,2, \ldots \mathrm{s} \\
\mathrm{v}_{\mathrm{i}}>\varepsilon, \mathrm{i}=1,2, \ldots \mathrm{m}
\end{gathered}
$$

with $\varepsilon>0$ and $u_{0}$ indicating the level of return to scale. If the value is positive, then there is an increase RTS (Return to Scale). On the contrary, if the value is negative, then the RTS decreases. Whereas if $\mathrm{u}_{0}=0$ then the VRS model becomes the same as the CRS as a result of constant RST value.

Technical efficiency can be obtained in two ways, those are model with input and output orientation. Model with input orientation sees efficiency as a decrease in input without changes in output values. On the other hand, the model with the output orientation sees the efficiency as an increase in output with a fixed input.

Here is a model of BCC linear equations with output orientation:

$$
\begin{aligned}
& \text { Maximize, } h_{0}-\varepsilon\left(s_{r}^{+}+s_{i}^{-}\right) \\
& \text {Subject to }=\sum_{j=1}^{n} \lambda_{j} x_{j}+s_{i}^{-}=x_{j 0} \\
& \text { oi }=1, \ldots ., \mathrm{m} \\
& \sum_{j=1}^{n} \lambda_{j} y_{\dot{j}}-s_{r}^{+}=h_{0} y_{\dot{j} 0} \\
& \text { or }=1, \ldots ., \mathrm{S} \\
& \sum_{j=1}^{n} \lambda_{j}=1 ; \lambda_{j} \geq 0
\end{aligned}
$$

Where:

$\mathrm{h}_{0}=$ efficiency score of $\mathrm{j}_{0}^{\text {th }}$ DMU,

$\varepsilon=$ a non-Archimedean value to enforce strict positivity of the weights

$\mathrm{y}_{\mathrm{rj}}=$ observed amount of $\mathrm{r}^{\text {th }}$ output produced by DMU j,

$\mathrm{x}_{\mathrm{ij}}=$ quantity of $\mathrm{i}^{\text {th }}$ input used by DMU $\mathrm{j}$,

$\mathrm{u}_{\mathrm{r}}=$ the weight given to output $r$ as determine by the linear programming,

$v_{i}=$ the weight given to input $\mathrm{i}$ as determine by the linear programming,

$\mathrm{n}=$ the number of DMUs,

$\mathrm{m}=$ the number of inputs used by each DMU,

$\mathrm{s}=$ the number of outputs produced by each DMU,

$\mathrm{j}_{0}=$ the DMU being assessed in the set of $j=1, \ldots, n$ DMUs,

$s_{i}^{-}=$the slacks (input excesses),

$s_{r}^{+}=$the slacks (output shortfalls), 
$\lambda_{j}=$ constrained to be bivalent, and

$\mathrm{o}=$ universal quantification.

\section{RESULTS AND DISCUSSION}

\section{Efficiency of Decision Making Unit}

The measurement of efficiency with Data Envelopment Analysis includes several stages, those are identifying the Decision Making Unit (DMU), identifying input and output variables, calculating the DMU efficiency, and achieving efficiency in inefficient DMU.

\section{Identifying the Decision Making Unit (DMU)}

The Decision-Making Unit (DMU) is a term used against units to be measured for efficiency. In this study, the DMU is the coffee processing units that produce Hs wet coffee and sold it directly. The processing Unit which became DMU in this research amounted to $40 \mathrm{DMU}$.

\section{Identifying Input and Output Variables}

Inputs in this study include red coffee, manpower, water, fuel, sacks, machine operating time and equipment depreciation costs. Mean while, the output in this research is Hs wet coffee products and advantages.

\section{Calculating the Efficiency}

Efficiency measurement of the coffee processing unit in Ngada Regency is important because since the beginning of the sale of ready-to-sell Hs coffee processing efficiency measurement has never been done so that the measurement of efficiency in this study is the beginning of the measurement of efficiency.

The efficiency of DMU processing unit calculated by using the outputoriented CCR and BCC model can be seen in Table 1. The assumption of the CCR model is the Constans Return to Scale (CRS) that the increase in input leads to an increase in proportional output and DMU operates at an optimum scale. The assumption of the BCC model is a variable that the increase of the input does not result in a proportional change of output. The DMU achieves efficiency when it acquires a value equal to 1 .

Based on Table 1, it is known that of the 40 DMU results processing units using the DEA CCR model, there are 9 efficient DMUs (22.5\%) and 31 inefficient DMUs (77.5\%). DMU 15 is inefficient DMU with the lowest score. In the BCC model analysis, there are 20 efficient DMUs (50\%) and 20 inefficient DMUs (50\%). DMU 3 is an inefficient DMU with the lowest score. An efficient processing unit DMU is a DMU processing unit which has done a combination of proper input usage so that it can maintain these conditions in processing Hs wet coffee. In Ngada Regency, an inefficient coffee processing unit emerged caused by the fact that in the coffee processing 
Table 1. Value of Technical Efficiency and Scale Efficiency of Coffee Processing Units in Ngada regency.

\begin{tabular}{|c|c|c|c|c|}
\hline UPH Name & $\begin{array}{l}\text { DMU } \\
\text { Number }\end{array}$ & $\begin{array}{c}\text { Technical Efficiency } \\
\text { (CRS) }\end{array}$ & $\begin{array}{c}\text { Technical Efficiency } \\
\text { (VRS) }\end{array}$ & $\begin{array}{c}\text { Scale } \\
\text { Efficiency }\end{array}$ \\
\hline Famasa 3 & 1 & 0.98343 & 1 & 0.98343 \\
\hline Famasa 4 & 2 & 0.96887 & 1 & 0.96887 \\
\hline Famasa 6 & 3 & 0.94029 & 0.99856 & 0.94164 \\
\hline Famasa 8 & 4 & 0.94143 & 0.99945 & 0.94195 \\
\hline Famasa 9 & 5 & 0.88514 & 0.99903 & 0.88600 \\
\hline Bowoso 5 & 6 & 1 & 1 & 1 \\
\hline Ateriji I & 7 & 0.88748 & 1 & 0.88748 \\
\hline Wongawali 1 & 8 & 0.98597 & 0.99799 & 0.98795 \\
\hline Wongawali 2 & 9 & 0.99347 & 0.99414 & 0.99932 \\
\hline Wongawali 5 & 10 & 1 & 1 & 1 \\
\hline Sinar Tani 3 & 11 & 0.83508 & 0.90832 & 0.91937 \\
\hline Sinar Tani 4 & 12 & 0.84595 & 0.95590 & 0.88498 \\
\hline Sinar Tani 6 & 13 & 0.92025 & 0.99833 & 0.92178 \\
\hline Papataki 3 & 14 & 0.96508 & 1 & 0.96508 \\
\hline Papataki 4 & 15 & 0.82646 & 1 & 0.82646 \\
\hline Papataki 6 & 16 & 0.93053 & 1 & 0.93053 \\
\hline Papataki 7 & 17 & 1 & 1 & 1 \\
\hline Papataki 11 & 18 & 1 & 1 & 1 \\
\hline Papataki 15 & 19 & 0.98571 & 1 & 0.98571 \\
\hline Papawiu 3 & 20 & 0.94733 & 1 & 0.94733 \\
\hline Sukamaju 2 & 21 & 1 & 1 & 1 \\
\hline Sukamaju 6 & 22 & 0.99800 & 1 & 0.99800 \\
\hline Sukamaju 3 & 23 & 0.93722 & 1 & 0.93722 \\
\hline Mezamogo 1 & 24 & 0.93522 & 1 & 0.93522 \\
\hline Lobobutu 1 & 25 & 0.88544 & 0.93121 & 0.95086 \\
\hline Lobobutu 2 & 26 & 0.90036 & 0.99947 & 0.90084 \\
\hline Lobobutu 4 & 27 & 0.97998 & 0.99856 & 0.98140 \\
\hline Lobobutu 5 & 28 & 0.87581 & 0.99947 & 0.87628 \\
\hline Peupalo 2 & 29 & 1 & 1 & 1 \\
\hline Peupalo 5 & 30 & 0.95876 & 0.99805 & 0.96063 \\
\hline Lapmas Bajawa 1 & 31 & 0.95671 & 0.99807 & 0.95856 \\
\hline Lapmas Bajawa 2 & 32 & 0.92280 & 0.95678 & 0.96449 \\
\hline Lapmas Bajawa 3 & 33 & 0.86931 & 0.99944 & 0.86981 \\
\hline Lapmas Bajawa 4 & 34 & 0.95543 & 0.99922 & 0.95618 \\
\hline Lapmas Bajawa 12 & 35 & 0.94334 & 0.95086 & 0.99209 \\
\hline Lapmas Golewa 1 & 36 & 1 & 1 & 1 \\
\hline Lapmas Golewa 3 & 37 & 1 & 1 & 1 \\
\hline Lapmas Golewa 4 & 38 & 1 & 1 & 1 \\
\hline Lapmas Golewa 5 & 39 & 0.96935 & 0.99980 & 0.96955 \\
\hline Lapmas Golewa 8 & 40 & 0.97038 & 0.99920 & 0.97116 \\
\hline
\end{tabular}

Source: DEA analysis results, 2018 
Table 2. Technical Efficiency and Scale Efficiency of Coffee Processing Unit in Ngada Regency.

\begin{tabular}{lcccc}
\hline Variable & Minimum & Maximum & Average & Standard Deviation \\
\hline TE (CRS) & 0.826462 & 1 & 0.947515 & 0.050304 \\
TE (VRS) & 0.908321 & 1 & 0.992046 & 0.020549 \\
SE & 0.909876 & 1 & 0.955112 & 2.44795 \\
\hline
\end{tabular}

Source: DEA analysis results, 2018

process, the allocation of inputs has not been allocated properly (Timisela et al., 2012; Wijayanti et al., 2016). There are still many processing units using raw material inputs, water, labor, machinery and excessive depreciation costs. This phonomenon is presumably because the management and members of the processing unit have not carried out the right combination of inputs in the processing of Hs wet coffee. Inefficient conditions mean that by using input in a fixed amount of production and technology, the output can increase or with the same output, at least one production input is used less (Lubis et al., 2014). Inefficient processing units can still increase output by paying more attention to input use.

Scale efficiency is a comparison ratio of CRS technique efficiency and VRS technical. Based on Table 1, it is known that the DMU of the yield processing units which reaches the optimal efficiency scale include DMU 6, $10,17,18,21,29,36,37$, and 38. This shows that the 9 DMUs are optimal in the use of inputs and can be used as a
DMU model for inefficient DMUs. Next, in Table 2, it is known that the average efficiency of UPH is the result of the DEA calculation of the CCR model which is 0.947515 and in the DEA calculation, the average processing unit efficiency of the BCC model is 0.992046 . This shows that the coffee processing unit has relatively good efficiency where the average value achieved is close to one.

To achieve efficiency, the results processing unit needs to make improvements in coffee processing activities related to the use of inputs for raw materials for logs, water, gasoline, labor, and equipment as well as internal skills and management in the results of processing unit.

The result of the DEA calculation of the VRS model also shows the return to scale condition of the coffee processing unit. It is known that the position of the return to the scale of the coffee processing unit is 9 processing units of coffee in constant return to scale, and 31 processing units in the condition of increasing return to scale. The cause of the coffee processing unit in the IRS condition is because the 
Table 3. Inefficient DMU, Reference DMU, and Reference Value of DEA Analysis Results from CCR Model at Coffee Processing Units in Ngada regency

\begin{tabular}{|c|c|c|c|c|c|c|c|c|}
\hline \multirow{2}{*}{$\frac{\mathrm{DMU}}{1}$} & \multicolumn{8}{|c|}{ Reference DMU (Reference Value) } \\
\hline & 10 & $(0.479)$ & 21 & $(0.021)$ & 37 & $(0.288)$ & & \\
\hline 2 & 10 & $(0.412)$ & 21 & $(0.040)$ & 37 & $(0.206)$ & 38 & $(0.003)$ \\
\hline 3 & 36 & $(0.083)$ & 37 & $(0.383)$ & & & & \\
\hline 4 & 6 & $(0.025)$ & 21 & $(0.017)$ & 29 & $(0.419)$ & & \\
\hline 5 & 6 & $(0.157)$ & 10 & $(0.233)$ & 21 & $(0.026)$ & & \\
\hline 7 & 10 & $(0.079)$ & 21 & $(0.189)$ & 38 & $(0.099)$ & & \\
\hline 8 & 10 & $(0.690)$ & 21 & $(0.026)$ & 37 & $(0.128)$ & & \\
\hline 9 & 10 & $(0.007)$ & 29 & $(0.513)$ & 37 & $(0.488)$ & & \\
\hline 11 & 6 & $(0.126)$ & 10 & $(0.179)$ & 17 & $(0.162)$ & 38 & $(0.031)$ \\
\hline 12 & 6 & $(0.094)$ & 10 & $(0.256)$ & 21 & $(0.048)$ & & \\
\hline 13 & 37 & $(0.358)$ & 38 & $(0.007)$ & & & & \\
\hline 14 & 6 & $(0.062)$ & 17 & $(0.053)$ & 29 & $(0.139)$ & & \\
\hline 15 & 6 & $(0.272)$ & 17 & $(0.034)$ & 38 & $(0.018)$ & & \\
\hline 16 & 6 & $(0.318)$ & & & & & & \\
\hline 19 & 6 & $(0.578)$ & 18 & $(0.001)$ & 21 & $(0.210)$ & 38 & $(0.053)$ \\
\hline 20 & 6 & $(0.357)$ & 18 & $(0.085)$ & & & & \\
\hline 22 & 10 & $(0.306)$ & 21 & $(0.515)$ & 37 & $(0.056)$ & & \\
\hline 23 & 37 & $(0.634)$ & & & & & & \\
\hline 24 & 6 & $(0.405)$ & 38 & $(0.095)$ & & & & \\
\hline 25 & 6 & $(0.071)$ & 10 & $(0.380)$ & 17 & $(0.124)$ & 38 & $(0.022)$ \\
\hline 26 & 6 & $(0.266)$ & 10 & $(0.091)$ & 21 & $(0.112)$ & & \\
\hline 27 & 6 & $(0.060)$ & 10 & $(0.579)$ & 21 & $(0.149)$ & & \\
\hline 28 & 10 & $(0.144)$ & 21 & $(0.138)$ & 37 & $(0.054)$ & & \\
\hline 30 & 37 & $(0.532)$ & & & & & & \\
\hline 31 & 37 & $(0.519)$ & & & & & & \\
\hline 32 & 37 & $(0.557)$ & & & & & & \\
\hline 33 & 21 & $(0.115)$ & 37 & $(0.165)$ & 38 & $(0.004)$ & & \\
\hline 34 & 6 & $(0.243)$ & 10 & $(0.312)$ & 17 & $(0.090)$ & 38 & $(0.006)$ \\
\hline 35 & 6 & $(0.317)$ & 17 & $(0.022)$ & 29 & $(0.252)$ & & \\
\hline 39 & 18 & $(0.366)$ & 21 & $(0.079)$ & 29 & $(0.244)$ & & \\
\hline 40 & 10 & $(0.534)$ & 21 & $(0.099)$ & 37 & & 38 & $(0.050)$ \\
\hline
\end{tabular}

Source: DEA analysis results, 2018

allocation of inputs used in the processing of Hs wet coffee is not right. Therefore, the processing unit which is in the IRS condition can reduce the number of certain inputs which are overused. It then leads to efficiency.

\section{Achieving Efficiency in Inefficient DM}

The Improvement of Inefficient DMU with DEA CCR Model

In the DEA analysis, in addition to knowing whether a unit or DMU is efficient or not can also be seen on how an inefficient DMU achieves efficiency. 
Table 4. Inefficient DMU, References DMU, and Reference Value of DEA Analysis Results from BCC model at Coffee Processing Units in Ngada regency.

\begin{tabular}{|c|c|c|c|c|c|c|c|c|c|c|c|c|c|}
\hline DMU & & & & & & Referenc & e DM & U (Refere & ace & alue) & & & \\
\hline 3 & 20 & $(0.615)$ & 36 & (0.135) & 37 & $(0.250)$ & & & & & & & \\
\hline 4 & 15 & $(0.120)$ & 18 & $(0.444)$ & 20 & $(0.364)$ & 36 & $(0.015)$ & 37 & $(0.058)$ & & & \\
\hline 5 & 15 & $(0.622)$ & 20 & $(0.291)$ & 37 & (0.087) & & & & & & & \\
\hline 8 & 6 & $(0.065)$ & 7 & $(0.203)$ & 10 & $(0.589)$ & 21 & $(0.025)$ & 37 & (0.117) & & & \\
\hline 9 & 29 & $(0.502)$ & 37 & $(0.498)$ & & & & & & & & & \\
\hline 11 & 15 & $(0.666)$ & 17 & $(0.032)$ & 18 & $(0.097)$ & 20 & $(0.027)$ & 21 & $(0.016)$ & 36 & (0.068) 37 & $(0.093)$ \\
\hline 12 & 20 & $(0.926)$ & 36 & $(0.014)$ & 37 & $(0.060)$ & & & & & & & \\
\hline 13 & 15 & $(0.750)$ & 37 & $(0.250)$ & & & & & & & & & \\
\hline 25 & 15 & $(0.211)$ & 20 & $(0.473)$ & 36 & $(0.120)$ & 37 & (0.195) & & & & & \\
\hline 26 & 15 & (0.349) & 18 & $(0.147)$ & 20 & $(0.335)$ & 36 & (0.117) & 37 & $(0.051)$ & & & \\
\hline 27 & 6 & (0.699) & 18 & $(0.014)$ & 20 & $(0.072)$ & 21 & $(0.071)$ & 37 & $(0.145)$ & & & \\
\hline 28 & 15 & $(0.690)$ & 20 & $(0.178)$ & 21 & $(0.083)$ & 37 & $(0.050)$ & & & & & \\
\hline 30 & 15 & $(0.550)$ & 37 & $(0.450)$ & & & & & & & & & \\
\hline 31 & 15 & $(0.508)$ & 20 & $(0.060)$ & 37 & $(0.432)$ & & & & & & & \\
\hline 32 & 15 & $(0.520)$ & 37 & $(0.480)$ & & & & & & & & & \\
\hline 33 & 15 & $(0.710)$ & 20 & $(0.151)$ & 21 & $(0.085)$ & 37 & $(0.054)$ & & & & & \\
\hline 34 & 6 & $(0.295)$ & 7 & $(0.058)$ & 20 & $(0.499)$ & 36 & $(0.031)$ & 37 & $(0.116)$ & & & \\
\hline 35 & 6 & $(0.384)$ & 14 & $(0.252)$ & 16 & $(0.013)$ & 18 & $(0.331)$ & 38 & $(0.020)$ & & & \\
\hline 39 & 15 & $(0.025)$ & 18 & $(0.188)$ & 20 & $(0.600)$ & 21 & $(0.144)$ & 36 & $(0.019)$ & 37 & $(0.024)$ & \\
\hline 40 & 6 & $(0.121)$ & 20 & $(0.482)$ & 36 & $(0.147)$ & 37 & $(0.250)$ & & 0.000 & & & \\
\hline
\end{tabular}

Source: DEA analysis results, 2018

An inefficient DMU will be efficient by requiring DMU frontier in an attempt to be efficient. Improvement of input and output variables in inefficient DMU is done by referring to the efficient DMU presence in the peer group (Table 3).

The peer group is an efficient grouping of DMU with inefficient DMU that can be specified for the improvement directives for inefficient DMUs. Inefficient DMUs will be efficient by setting the input usage of the recommended percentage value of the DMU lambda value efficiently in the peer group (Lubis et al., 2014; Oktari et al., 2017).
Based on the results of the DEA analysis, the CCR model in Table 3 shows that 31 DMUs of processing units are not yet efficient. In order to achieve efficiency, the DMU processing unit must refer to the DMU of the efficient processing unit in the peer group. As an example of DMU 2 which has not been efficient, then to achieve DMU 2 efficiency, it must refer to DMU 10, 21, 37 and 38. DMU achieves efficiency if the input can reach the target by performing DMU multiplication and addition calculations efficiently with lambda value. Calculations to achieve DMU 2 efficiency = DMU 10 (0.412) 
+ DMU 37 (0.206) + DMU 21 (0.040)

+ DMU 38 (0.003). The results of this calculation project is that the DMU 2 will be efficient by reducing the water input by $19.56 \%$, machine working hours by $0.15 \%$, and depreciation costs by $6.17 \%$ and increasing Hs wet coffee output by $3.21 \%$ and profits by $6.34 \%$.

\section{The Improvement of Inefficient DMU with DEA BCC Model}

The calculation of the DEA efficiency of the BCC model shows that 20 DMU processing units are not efficient yet. Therefore, in order to achieve efficiency, the DMU must refer to the efficient DMU in the peer group by adjusting the input with efficient lambda DMU values. The method of repairing the DMU of the processing unit with the inefficiency of the BCC model is the same as the method of improvement in the CCR model. In Table 4 , it can be seen that in each DMU, the inefficient processing unit has an efficient processing unit DMU.

As an example, one of the inefficient DMUs is DMU 3. Thus, to be efficient, DMU 3 must refer to the value of lambda DMU 20, 36 and 37. Steps to improve DMU 3 = DMU 20 (0.615) + DMU 36 (0.135) + DMU 37 (0.250). This calculation results in projections of reducing raw material input usage by $6.07 \%$, fuel by $6.15 \%$, machine working hours by $11.05 \%$, labor by $14.11 \%$, and depreciation costs by $21.63 \%$ and increasing Hs wet coffee products by $0.14 \%$ and profit of $6.77 \%$.

\section{CONCLUSION AND SUGGESTION}

Based on the results of the study, it can be concluded that the coffee processing unit in Ngada Regency has not reached maximum efficiency. Efficient calculations using the DEA CCR model show that there are only 9 efficient processing units or $22.5 \%$, while 31 other processing units are inefficient. Meanwhile, with the BCC model, an efficient coffee processing unit is 20 units or $50 \%$ and 20 other processing units or $50 \%$ are not yet efficient. The projection of improvement of input and output variables in the inefficient coffee processing unit based on DEA CCR model and BCC model is by reducing all the inputs used by DMUs. These inputs to be reduced are raw material water, fuel, sack, machine working hours, labor, and depreciation costs so it can

increase the output of wet coffee products and profit.

\section{REFERENCES}

Abidin, Z., \& Endri, E. (2010). Kinerja Efisiensi Teknis Bank Pembangunan Daerah: Pendekatan Data Envelopment Analysis (DEA). Jurnal Akuntansi Dan Keuangan, 11(1). 
Banker, A. R. D., Charnes, A., \& Cooper, W. W. (1984). Some Models for Estimating Technical and Scale Inefficiencies in Data Envelopment Analysis Some Models For Estimating Technical and Scale Inefficiencies in Data Envelopment Analysis. Manajement Science, 30(9), 1078-1092.

Lubis, R. R. B., Daryanto, A., \& Tambunan, M. (2014). Analisis Efisiensi Teknis Produksi Nanas: Studi Kasus Di Kabupaten Subang, Jawa Barat. Jurnal Agro Ekonomi, 32(2), 91106.

Oktari, R. D., Waluyati, L. R., \& Suryantini, A. (2017). Pineapple Chips Business Efficiency Analysis in Kampar Regency Riau Province Using Data Envelopment Analysis (Dea) Method. Agro Ekonomi, 27(1), 64-78.

Sari, S. W., Nurmalina, R., \& Setiawan, B. (2014). Efisiensi Kinerja Rantai Pasok Ikan Lele di Indramayu, Jawa Barat. Jurnal Manajemen \& Agribisnis, 11(1), 12-23.

Soemarno, D., Mawardi, S., Maspur, M., \& Prayuginingsih, H. (2009). Added Valusae Improvement on Arabica Coffee Wet Process MethodUsing Model Kemitraan Bermediasi
(Motramed) on Unit Pengolahan Hasil at Ngada Residence-NTT. Pelita Perkebunan (a Coffee and Cocoa Research Journal), 25(1), 38-55.

Sudjarmoko, B. (2013). Prospek pengembangan industrialisasi kopi Indonesia. SIRINOV. Balai Tanaman Rempah Dan Aneka Tanaman Industri. 1 (3), 99-110.

Timisela, N. R., Darwanto, D. H., \& Hartono, S. (2014). Manajemen Rantai Pasok dan Kinerja Agroindustri Pangan Lokal Sagu di Propinsi Maluku: Suatu Pendekatan Model Persamaan Struktural. Agritech, 34(2), 184 193.

Timisela, N. R., Masyhuri, M., Darwanto, D. H., \& Hartono, S. (2012). Efisiensi Relatif Agroindustri Berbasis Pangan Lokal Sagu: Suatu Pendekatan Data Envelopment Analysis (DEA). Budidaya Pertanian, 8(2), 117-122.

Wijayanti, D. E., Hartono, S., \& Darwanto, D. H. (2016). Relative Efficiency of Brown Sugar Agroindustry in Kokap District, Kulon Progo Regency, D.I. Yogyakarta. Agro Ekonomi, 27(1), 52-63. 